\title{
As tecnologias e culturas digitais na educação a distância
}

Resumo: O desenvolvimento das tecnologias da informação e comunicação (TIC) conectadas em rede foi um dos grandes acontecimentos do século XX. Estas tecnologias potencializaram novas formas de aprender, interagir e se relacionar transformando diferentes setores entre eles a educação e a cultura. Nesse artigo, são apresentados aspectos interativos das TIC para a educação a distância, bem como são discutidos processos de virtualização, hipertextualidade e interatividade. A partir das reflexões apresentadas conclui-se que os responsáveis pela comunicação/educação tem como desafio mudar o paradigma tradicional da educação, baseado linearmente na emissão e recepção de informações, para outra perspectiva educacional onde a comunicação e a relação professor/aluno seja horizontal e interativa.

Palavras-chave: Virtualização, Interatividade, Hipertextualidade, Educação

\section{The technologies and digital cultures for distance education}

\begin{abstract}
The development of information and communication technologies (ICT) networked was one of the greatest events of the twentieth century. These technologies potentiated new ways of learning, interacting and relating to each other, and they are transforming various sectors, including education and culture. In this paper, we present interactive aspects of ICT for distance education as well as we discuss processes of virtualization, hypertextuality and interactivity. From the reflections presented here, it is concluded that the ones responsible for communication / education are being challenged to change the traditional linear paradigm of education, which is based on the emission and reception of information, to another educational perspective, in which communication and relationship between teachers and students happen horizontaly and interactively.
\end{abstract}

Keywords: Virtualization, Interactivity, Hypertextuality, Education

Artigo recebido em 31/10/2015 e aprovado em 07/01/2016. 


\section{AS TECNOLOGIAS E CULTURAS DIGITAIS NA EDUCAÇÃO A DISTÂNCIA}

SIMONE LUCENA

\section{Preâmbulo}

A Ideia não dispõe de qualquer atualidade. Ela é virtualidade pura ${ }^{\text {II }}$

Desde o início desse século XXI a internet tornou-se a mídia de maior acesso e divulgação da informação em todas as áreas, desde projetos educacionais a propagandas publicitárias. Trata-se de uma grande rede de comunicação onde as pessoas interagem de diversas maneiras, superando a modalidade comunicacional convencional utilizada pelas mídias massa. Com a popularização da internet nas sociedades mundiais, as agências de notícias deixaram de ser as únicas a veicular informações. Isso porque com a web todos tem a possibilidade de serem também produtores de informações e divulgadores de conteúdos. $\mathrm{O}$ diferencial dessa nova mídia digital está no fato de todos potencialmente serem a(u)tores, aqueles que criam informações e que muitas vezes também atuam, interagem nas interfaces e nas redes sociais da internet.

Para Castells" internet "é mais que uma tecnologia. É um meio de comunicação, de interação e de organização social". O desenvolvimento e a disseminação das tecnologias digitais e da internet trouxeram grandes transformações para todos os setores da sociedade. A partir do uso destas tecnologias passamos a vivenciar o que chamamos aqui de culturas digitais que são as maneiras pelas quais os praticantes sociais se apropriam dos artefatos tecnológicos e com eles criam formas próprias de utilizá-los nas suas atividades e ações cotidianas.

As culturas digitais potencializam novos espaços e tempos para a educação no século $\mathrm{XXI}$, entretanto ainda não poucas as experiências educacionais que conseguem utilizar as potencialidades que esta cultura proporciona. A educação a distância $(\mathrm{EaD})$, por ser uma modalidade educacional cuja mediação por meio das tecnologias é imprescindível, deveria ser a modalidade com maior uso das interações possibilitadas pelas culturas digitais, mas nem sempre isso ocorre. Em geral, a $\mathrm{EaD}$ utiliza as tecnologias digitais na mesma lógica comunicacional das mídias de massa, ou seja, no sentido unidirecional um-todos.

As tecnologias digitais ampliam e redimensionam alguns processos já vivenciados pelos seres humanos antes mesmo do desenvolvimento destas tecnologias tais como: a virtualização, a hipertextualidade e a interatividade. Cabe a educação a distância encontrar possibilidades para que estes processos possam ser utilizados na produção de conhecimentos construídos de forma colaborativa e em rede.

\section{A virtualização na educação}

O termo virtualização ou virtualidade tornou-se mais utilizado após o desenvolvimento dos computadores e das redes digitais. A virtualização, entretanto, é predecessora das tecnologias, pois trata-se de tudo aquilo que possui existência potencial ou que possivelmente poderá acontecer, isso é, factível. Etimologicamente, 'virtual' deriva do latim 'vir' (que significa homem em um sentido idealizado), de onde derivou o termo 'virtus' (força, masculinidade, potência, virtude). Segundo o Dicionário de Tecnologia ${ }^{I V}$ 'virtual', no inglês da Idade Média, referia-se à qualidade de alguém "possuidor de certas virtudes físicas".

Pela via do senso comum, associa-se o virtual a tudo que é falso, imaginário, ilusório ou não material. Lévy ${ }^{\mathrm{V}}$ considera que o virtual possui apenas uma afinidade com estas Cadernos do Tempo Presente, n. 22, dez.2015/jan. 2016, p. 16-29|http://www.seer.ufs.br/index.php/tempo 


\section{AS TECNOLOGIAS E CULTURAS DIGITAIS NA EDUCAÇÃO A DISTÂNCIA}

\section{SIMONE LUCENA}

categorias, não se opondo ao real, pois trata-se apenas de "um modo de ser fecundo e poderoso, que põe em jogo processos de criação, abre futuros, perfura poços de sentidos sob a platitude da presença física imediata". Ainda segundo Lévy, na mesma obra citada, a digitalização e o ciberespaço ampliaram as possibilidades de virtualização, mas sua amplitude vai além das redes digitais, pois a memória, a imaginação, os sonhos e os desejos são também outras formas de virtualidade.

Casteslls ${ }^{\mathrm{VI}}$ acredita que a realidade, na forma como ela se apresenta, sempre foi virtual, uma vez que ela quase sempre é percebida por meio de símbolos, de representações. Neste sentido, a virtualização faz parte da criação da humanidade, presente na história de vida de cada ser humano, em todos seus aspectos - sociais, econômicos, políticos, culturais e educacionais. Por este motivo, Bonilla ${ }^{\mathrm{VII}}$ percebe a importância de os educadores compreenderem

a relação virtual e real, haja visto a educação estar comprometida com o movimento de heterogênese do humano, com os processos de produção de conhecimento, imaginação e aprendizagem, os quais estão intimamente relacionados a processos de virtualização.

Outros autores como Deleuze ${ }^{\mathrm{II}}$, Serres ${ }^{\mathrm{VIII}}$ e Lévy ${ }^{\mathrm{V}}$ se dedicaram aos estudos sobre virtualidade. Este último autor, na obra $O$ que é virtual, propõe uma análise do termo considerando os aspectos filosófico, antropológico e sócio-político. A análise feita por Lévy ${ }^{\mathrm{V}}$ utiliza as categorias possível/real como complementares do virtual/atual.

O possível é algo já constituído com todas as suas características, mas em que falta ainda a materialidade, a existência. Para Deleuze ${ }^{\mathrm{IX}}$, “o possível opõe-se ao real; o processo do possível é, pois, uma 'realização"'. O virtual é um real sem materialidade, mas que também existe. Possível e virtual são latentes, "anunciam antes um futuro do que oferecem uma presença" (LÉVY $\left.{ }^{\mathrm{X}}\right)$. Para Bonilla $\mathrm{XI}$, "como uma possibilidade está associada a uma potencialidade, o possível está imbricado no virtual”.

Todavia o real e o atual são patentes e manifestos, eles estão presentes. Desta forma, o virtual não é imaginário nem oposto ao real, ele é uma parte do real e opõe-se ao atual. Segundo Lévy, “o virtual é uma fonte indefinida de atualizações"XII. As quatro categorias: possível, real, virtual e atual formam quatro polos dialéticos. Para Lévy, possível/real estão no polo das substâncias e virtual/atual estão no polo dos acontecimentos.

$\mathrm{Na}$ relação virtual/atual surgem dois processos distintos e característicos da espécie humana: a virtualização, que é a passagem do atual para o virtual, compreendendo o remontar de uma solução problematizadora, e a atualização, que é a passagem do virtual para o atual, compreendendo uma solução exigida num complexo problemático.

Se a atualização é uma resposta a uma dada problematização, e a virtualização significa o retorno a uma nova problemática, podemos perceber que esse movimento dialético faz parte do próprio processo de aprendizagem do ser humano ao longo da sua existência. Nesta perspectiva, é impossível desvincular o par virtual/atual da instância do sentido e do simbólico ${ }^{\mathrm{XIII}}$.

As tecnologias digitais potencializam o virtual ao possibilitar que algo seja deslocalizado e desmaterializado. Percebe-se, que estas tecnologias redimensionam as 
categorias de espaço e de tempo, que não representam mais o calendário ou o relógio como nas antigas gerações, mas se misturam e se intercruzam. $\mathrm{O}$ virtual não está presente apenas em um determinado lugar, mas ele se manifesta em diferentes momentos e locais, tornando-se assim desterritorializado.

O fato de algo não pertencer a um determinado lugar não significa que não exista. Por exemplo, nas redes sociais ou nos ambientes virtuais de aprendizagem da $\mathrm{EaD}$, seus membros estão espalhados em locais distintos e utilizam as interfaces da internet para se comunicar ou para discutir assuntos de interesses comuns. Desta maneira, a rede social está virtualmente presente na web e atualiza-se em qualquer lugar onde seus membros estejam conectados.

A virtualização da informação nos hipertextos na internet possibilita que cada sujeito possa atualizá-la constantemente criando assim novos percursos de aprendizagem que poderão ser modificados, indexados, decompostos, recompostos e disponibilizados novamente por outros sujeitos.

\section{Hipertextualidade como pressuposto da EaD}

A melhor forma de buscar compreender o que é um hipertexto talvez seja tentar relacioná-lo com o próprio pensamento humano (Lévy) ${ }^{\mathrm{XIV}}$, que se desenvolve por meio de associações entre o conhecimento já existente e o novo aprendizado. $\mathrm{O}$ termo hipertexto ganha notoriedade com o desenvolvimento da internet, particularmente a partir da década de 1990, porém foi pensado mais detalhadamente desde 1945 por Vannervar Bush quando criou o Memex (Memory Extension). Tratava-se de um dispositivo utilizado para auxiliar a memória a guardar conhecimentos/informações. O Memex ajudaria principalmente os cientistas a construírem novos conhecimentos e interligá-los aos já existentes por associações.

As contribuições de Bush ajudaram Theodore Nelson, em 1963, a criar o termo hipertexto como forma de "exprimir a ideia de escrita/leitura não linear em um sistema de informática" (Lévy) ${ }^{\mathrm{XV}}$. O sistema imaginado por Nelson recebeu o nome de Xanadu. Este sistema seria um grande banco de dados onde as pessoas poderiam armazenar informações, escrever, interagir, interconectar-se, comentar os textos já arquivados, trocar imagens, som e filmes. As informações poderiam ser acessadas de forma não linear, de acordo com a rota de navegação criada por cada pessoa. Como este sistema seria um banco de dados, os direitos autorais seriam pagos em royalites aos autores caso fosse necessária a utilização de citações originais. O Xanudu seria um enorme banco de dados que, pretensiosamente, disporia de todo o conhecimento da humanidade. Faltou a Nelson, contudo, naquela época, equipamentos com a capacidade para armazenar tamanho sistema.

Machado $^{\mathrm{XVI}}$ relata que, no século XIX, o poeta Mallarmé havia pensando em construir um livro múltiplo, onde seria possível encontrar potencialmente todos os outros livros possíveis. O Livre de Mallarmé "deveria ter uma forma móvel, seria mesmo um processo infinito de fazer-se e refazer-se, algo sem começo e sem fim, que apontaria continuamente para novas possibilidades de relações e horizontes de sugestões ainda não experimentados"XVII . Como Mallarmé nesse período também não possuía meios de realizar seu Livre, ele nunca saiu de um simples esboço exposto no Lance de Dados (1897), um poema-constelação escrito em forma não linear como o próprio projeto do Livre.

Tanto o Memex como o Xanadu e o Livre serviu de base para o desenvolvimento da internet. A internet é hoje um imbricamento de hipertextos, uma rede de redes, sendo, por este motivo, chamada de "memória global e enciclopédia coletiva da humanidade"XVIII. 


\section{AS TECNOLOGIAS E CULTURAS DIGITAIS NA EDUCAÇÃO A DISTÂNCIA}

\section{SIMONE LUCENA}

O hipertexto é apontado por Machado como "o grande divisor de água entre o antigo e o atual conceito de livro"XIX . Este autor lembra que os primeiros escritos da humanidade foram registrados em tábuas de cera, no pergaminho e depois no papel. Hoje, com o desenvolvimento do computador e da internet, o hipertexto digitalizado trouxe uma nova forma de escrita rizomática, semelhante ao próprio pensar humano, e uma leitura não retilínea e sequencial, que se atualiza de forma diferenciada para cada sujeito que nele interage. Os caminhos escolhidos por cada pessoa variam de acordo com os links que ela escolhe prioritariamente. Estes links poderão ser palavras, figuras, sons, ícones ou vídeos, que podem conter outros nós ou mesmo uma rede inteira.

Segundo Lemos ${ }^{X X}$, ao navegar pela internet que devemos nos deixar perder no mar de informação e nos afogarmos nas malhas da rede, pois haveria aí possibilidades de, ao invés de encontrarmos um porto seguro que nos levaria apenas às informações necessárias, estarmos abrindo a possibilidade de encontrar novos caminhos que nos levariam a novos conhecimentos ainda não imaginados. $\mathrm{O}$ mesmo nos sugere Brandão com relação às bibliotecas. Para ela, não basta apenas usar a biblioteca para empréstimos de livros

estar na biblioteca manuseando periódicos, pesquisando temas e descobrindo autores, conhecendo obras de referência (dicionários, enciclopédia, bancos de dados, anuários e anais de congressos) é experiência indispensável à constituição de habitus científico. $^{\mathrm{XXI}}$

A internet também nos oferece bibliotecas virtuais ${ }^{\mathrm{XII}}$ onde é possível consultar artigos, teses, dissertações, periódicos e diversas informações necessárias a todo pesquisador, constituindo-se em uma forma imprescindível de consulta, pois ela irá nos oferecer informações em nível amplo e atualizado, uma vez que todo hipertexto é passível de atualizações constantes. Esta é uma das diferenças entre o texto impresso e o texto digital.

O texto impresso também permite ao leitor uma leitura não linear, pois ele poderá escolher no índice por qual capítulo ou tema deseja iniciar a leitura. As notas de rodapé são ainda outra forma de leitura não hierarquizada. Porém um hipertexto na internet possui uma dimensão mais ampla, pois ele poderá conter links que levarão o leitor a outros sites com outras fontes de informação e outros textos, traçando, assim, uma estrutura em forma de rizoma em diversas direções. Isso implicará também em uma mudança na velocidade de se buscar a informação. Neste sentido, Nielsen ${ }^{\text {XXIII }}$ ressalta que "o hipertexto é a base da Web e que nenhum site é uma ilha". Por este motivo, é importante que o hipertexto contenha links externos que possibilitem a navegação pelo ciberespaço. Um hipertexto apenas com links internos, onde o internauta navega em forma circular, pode tornar-se um hipertexto desinteressante, quebrando a estrutura rizomática da rede. Para a EaD é extremamente importante que os conteúdos sejam disponibilizados na forma de hipertexto com diferentes links que possibilitem aos sujeitos construir seu roteiro de estudo e de aprendizagens.

A hipertextualidade, assim como a virtualidade, faz parte do processo de desenvolvimento do conhecimento humano, sendo, importante, por este motivo, a sua compreensão para a educação. Além disso, é preciso ainda conhecer e saber também utilizar a interatividade como forma comunicacional nas relações sociais e sobretudo na relação educacional.

\section{Interatividade: por um "mais comunicacional" na Web}

A literatura sobre interatividade, muitas vezes, refere-se a este termo como sendo apenas a relação entre a pessoa humana e a máquina, mais precisamente o computador. 


\title{
AS TECNOLOGIAS E CULTURAS DIGITAIS NA EDUCAÇÃO A DISTÂNCIA
}

\author{
SIMONE LUCENA
}

Acredita-se que a utilização do termo interatividade intensificou-se com a telemática nos anos de 1980 e que se consolidou por volta do ano de 1997 quando a internet se popularizou e passaram a ser criados sites utilizando a linguagem HTML, contendo links que aumentavam a comunicação entre o indivíduo e o computador. Um dos autores que apresenta uma discussão sobre interatividade é Lévy

o termo "interatividade" em geral ressalta a participação ativa do beneficiário de uma transação de informação. De fato, seria mostrar que o receptor de informação, a menos que esteja morto, nunca é passivo. Mesmo sentado na frente de uma televisão sem controle remoto, o destinatário decodifica, interpreta, participa, mobiliza seu sistema nervoso de muitas maneiras, e sempre de forma diferente de seu vizinho ${ }^{\text {XIV }}$.

Não há como dizer que um receptor é alguém passivo, porém é preciso buscar uma definição melhor para o termo interatividade que não o restrinja apenas à relação pessoa humana/máquina.

Silva ${ }^{\mathrm{XV}}$, ressalta que o termo "interatividade" está sendo utilizado no interior de uma perspectiva que se caracteriza pela elasticidade. No entanto, ele discorda que a interatividade possa estar restrita apenas à relação pessoa humana-máquina. Para Silva, "o termo 'interatividade' foi posto em destaque com o fim de especificar um tipo singular de interação"XXVI. Interação tornou-se um termo vasto que não mais conferia acepções contidas na interatividade. Este autor considera ainda que para que um objeto, seja ele uma obra de arte, um equipamento ou mesmo uma comunicação, possa ser considerado interativo, ele deverá estar "imbuído de uma concepção que contemple complexidade, multiplicidade, não

linearidade, bidirecionalidade, potencialidade, permutabilidade (combinatória), imprevisibilidade, etc., permitindo ao usuário-interlocutor-fruidor a liberdade de participação, de intervenção e de criação" (idem, p. 105). Desta forma, Silva acredita que a interatividade seria mais que uma interação, seria uma "hiper-interação"XXVII.

$\mathrm{O}$ artista e teórico Couchot ${ }^{\mathrm{XXVIII}}$ também apresenta-nos uma discussão sobre a interatividade na arte. Ele considera importante a participação interativa do público e chama de arte participacionista aquela na qual o espectador participa da obra, sendo que esta "não é mais fechada sobre si mesma, fixa no seu acabamento; ela 'se abre'. (...) O artista delega ao observador uma parte de sua responsabilidade de autor"XXIX .

Para Lévy ${ }^{\mathrm{XX}}$, as tecnologias digitais são os únicos dispositivos que oferecem um amplo grau de interatividade no sentido "todos-todos". Os demais dispositivos comunicacionais são proporcionadores de diferentes tipos de interatividade. Desta forma, ele distinguiu três categorias de dispositivos: "um-todos" ou difusão unilateral, em que, a partir de um centro emissor, as informações são distribuídas para um grande número de receptores, sendo os meios de comunicação de massa como rádio, televisão, revistas e jornais exemplos desse tipo de dispositivo; o outro dispositivo comunicacional seria no sentido "um-um" ou diálogo, reciprocidade ou ainda ponto a ponto, onde somente duas pessoas se comunicam, como acontece ao usar o telefone ou o correio; o dispositivo "todos-todos" ou diálogo entre vários participantes permite que estes possam interagir uns com os outros como acontece nos ambientes virtuais da internet. Neste sentido a interatividade, para Lévy, acontece baseada em dispositivos informacionais e comunicacionais, sendo a internet o espaço onde esta interatividade poderá acontecer de forma mais ampla. 


\section{AS TECNOLOGIAS E CULTURAS DIGITAIS NA EDUCAÇÃO A DISTÂNCIA}

\section{SIMONE LUCENA}

Queremos destacar que não acreditamos que a interatividade possa ser apenas relacionada com o uso das tecnologias digitais: partimos do suposto que as tecnologias podem potencializar a interatividade, mas que ela sempre irá existir independentemente da base tecnológica utilizada, pois interatividade é comunicação e, por este motivo, ocorre tanto na esfera social como pode ocorrer também na esfera tecnológica. Nesse sentido, Silva conceitua a interatividade como sendo uma

disponibilização consciente de um mais comunicacional de modo expressivamente complexo, ao mesmo tempo atentando para as interações existentes e promovendo mais e melhores interações - seja entre usuários e tecnologias digitais ou analógicas, seja nas relações "presenciais" ou "virtuais" entre seres humanos XXXI.

Para conseguirmos obter a interatividade, de acordo com este autor, é preciso perceber se um determinado objeto, obra de arte ou mesmo equipamento digital, possui os fundamentos da interatividade, que ele classifica em três binômios: participação-intervenção, bidirecionalidade-hibridação e potencialidade-permutabilidade. Silva chama a atenção de que estes fundamentos estão interligados.

Ao pensarmos na EaD baseada nas tecnologias digitais e conectada a internet é imprescindível a utilização da interatividade nos ambientes de aprendizagem, pois para a construção de conhecimentos online é importante a existência da interatividade com o outro, seja ele o professor, o tutor ou o colega. É preciso disponibilizar nos cursos de EaD espaços interativos onde a comunicação possa ocorrer no sentido todos-todos e não apenas numa via de mão dupla restrita apenas a professor $\leftrightarrow$ aluno.

\section{A necessidade de interatividade na EaD}

Os cursos de EaD no Brasil com a utilização de dispositivos tecnológicos tiveram seu início por meio de transmissões via rádio e posteriormente via televisão, visando promover a qualificação profissional de trabalhadores que moravam distante das instituições escolares. Estes cursos tinham uma perspectiva de auto-aprendizagem. Programas utilizando conjuntamente vídeo e televisão só começaram a aparecer a partir da década de 1980. Outros, utilizando tecnologias digitais como CD-ROM e internet, começam a surgir em meados dos anos 1990, porém com a mesma perspectiva dos primeiros ${ }^{\text {XXII }}$.

Uma das instituições pioneiras em cursos de $\mathrm{EaD}$ no Brasil foi o Instituto Universal Brasileiro $^{\text {XXIIII }}$, que, desde a década de 1940, disponibilizava aulas por correspondência, onde o aluno recebia o material didático em casa, respondia as questões e mandava-as de volta ao Instituto. Hoje, esta mesma instituição utiliza a internet para oferecer cursos à distância com a mesma perspectiva anterior mudando apenas de suporte tecnológico. As aulas restringem-se à leitura de textos e realização de questionários. Podemos perceber que esta é uma forma de subutilizar a internet e de torná-la apenas um instrumento didático motivador de aulas tradicionais (Pretto ${ }^{\text {XXIV }}$ ). Se o paradigma educacional não muda, possibilitando ao sujeito ser a(u)tor, construtor do seu conhecimento, então as tecnologias servirão apenas para ilustrar as velhas práticas pedagógicas. 


\section{AS TECNOLOGIAS E CULTURAS DIGITAIS NA EDUCAÇÃO A DISTÂNCIA}

SIMONE LUCENA

Desde 1996, quando a atual Lei de Diretrizes e Bases (LDB) da educação nacional entrou em vigor, as instituições de ensino passaram a contar com a possibilidade de oferecer cursos de educação à distância em todos os níveis de ensino. Esta mesma lei também estabeleceu que todos os professores de ensino fundamental e médio deveriam ter curso superior e, para aqueles que ainda não o possuíam, foi dado um prazo relativamente curto para a sua realização. Neste contexto, os cursos de EaD passaram a ser uma alternativa para o cumprimento da lei.

Nos últimos anos, temos percebido um aumento no número de cursos de EaD. Porém o que nos chama a atenção são os desenho didáticos utilizados pela maioria destes cursos, pois a maioria utiliza, no processo ensino-aprendizagem, a lógica tradicional e linear de transmissão de conteúdos. Assim sendo, nos ambientes de aprendizagem dos cursos a distância os conteúdos são apresentados de forma sequencial com um hipertexto fechado onde o aluno não tem a possibilidade de participar e intervir amplamente.

Nesse sentido, percebe-se que a EaD transformou-se em estratégia rápida com baixo custo e capaz de oferecer a qualificação para um grande número pessoas geograficamente distantes. Utilizada nesta perspectiva, podemos denominá-la de educação de massa, onde as tecnologias digitais passaram a ser empregadas como instrumento pedagógico que melhor atende ao modelo de educação tradicional revestido de uma lógica de comunicação no sentido broadcasting. Esta forma de comunicação distribui a informação em larga escala sem considerar as especificidades de cada cultura e da realidade escolar. Certamente em muito pouco esta maneira de ensinar e aprender se diferencia da "educação bancária" criticada por Paulo Freire ${ }^{\mathrm{XXX}}$.

As tecnologias da informação e da comunicação (TIC) vêm contribuindo para a modificação da forma de as pessoas se relacionarem e de construírem conhecimentos, pois elas proporcionam múltiplas disposições à intervenção do "interagente"XXXVI. Estas novas modalidades comunicacionais proporcionadas pela presença das TIC criam novos tempos e espaços interativos descentralizados, não lineares e provocam mudanças estruturais na forma de se produzir, distribuir e compartilhar a informação, passando de um sistema "Um-Todos" para "Todos-Todos". Na rede todos os nós são centros XXXVII , ligados entre si, formando uma teia, onde os conhecimentos são permanentemente (re)construídos, a partir das inter-relações entre os sujeitos.

Nesse sentido, será que educação à distância na era tecnológica, das culturas digitais e diante de uma geração digital que, tem outra maneira de perceber e de se relacionar com o mundo poderá deixar de contemplar a interatividade na relação de aprendizagem? Por que não pensarmos em construir ambientes virtuais para a educação online que desafiem o aluno a interagir, a construir o conhecimento, escolhendo seus próprios caminhos?

As possibilidades tecnológicas para o desenvolvimento de uma $\mathrm{EaD}$ interativa já existem, contudo os desafios colocados hoje para a educação são sobretudo de ordem pedagógica e econômica. Há uma necessidade de preparar os professores para atuar com essas tecnologias, pois, como já percebemos, eles não poderão mais ser simplesmente professores convencionais com a mesma postura de disseminador de informações. Será importante que o professor, além dos conhecimentos teóricos e tecnológicos, esteja aberto para o mais comunicacional, para deixar o aluno expor suas ideias e trilhar seus próprios caminhos. $\mathrm{O}$ professor não poderá mais ser aquele que "conduz o aluno a", mas quem o desafiará a entrar no labirinto, mergulhar no mar de informações, interligar os saberes e buscar as soluções para os seus problemas, construindo assim - conhecimentos. 


\section{Epílogo}

No meio dessas discussões, temos ainda uma geração interativa - chamada pelos teóricos de "geração digital"XXXVIII ou "polegarzinha"XXXIX - na sua maneira de ser, de se relacionar, de agir e que, por esta razão, concebe o mundo de uma outra forma, apresentando grandes desafios a comunicadores/educadores. Trata-se de uma geração questionadora, que não aceita mais a condição de espectador ou receptor. Deseja interagir. Neste sentido, os responsáveis pela comunicação/educação passam a ter como desafio mudar seu paradigma tradicional baseado linearmente na emissão e recepção de informações, para uma outra perspectiva educacional onde a comunicação e a relação professor/aluno seja horizontal e interativa.

A emergência de um novo público, que não é mais apenas consumidor de informação e de produtos, mas são sujeitos críticos, questionadores que também querem ser ouvidos e desejam expôr suas experiências e visão do mundo e das coisas que os cercam. Contudo, há de se questionar em que medida a interatividade está sendo concretizada nos cursos ofertados na modalidade a distância ?

A interatividade descrita como um mais comunicacional contempla alguns princípios interligados que caracterizam uma comunicação interativa. Estes princípios são: participaçãointervenção, bidirecionalidade-hibridação e permutabilidade-potencialidade. $O$ que encontramos na maioria dos cursos de $\mathrm{EaD}$ são apenas possibilidades de participação e intervenção do sujeito dentro das atividades produzidos pela instituição educacional. Desta forma, questionamos: é possível ser interativo quando interesses políticos e econômicos precisam ser priorizados?

Percebemos que a utilização das TIC no ambiente escolar possibilita um repensar da educação dentro de uma outra perspectiva comunicacional que contemple a interatividade como principal fundamento na relação entre professor e aluno. Entendemos que a escola poderá ser um espaço de aprendizagens que emergem de várias experimentações, incluindo também as experiências realizadas nos ambientes virtuais. Contudo, isso nos leva a questionar qual será a função do professor nesse novo ambiente virtual onde tudo acontece ao mesmo tempo agora, o tempo todo? Com certeza ele não será mais o centralizador do conhecimento e, por esse motivo, é importante que ele esteja aberto ao mais comunicacional com os alunos para que juntos possam exercitar a autoria e a coautoria, utilizando a rede também como meio disponibilizador de suas produções.

Para trabalhar com as tecnologias e culturas digitais na sala de aula presencial ou a distância, o professor terá que se colocar aberto para o novo, o inesperado, pois cada aluno irá trilhar caminhos diferentes e difíceis de serem previstos. É neste sentido que acreditamos que com a interatividade não será possível haver determinações a priori e o professor não será mais transmissor de conteúdos. É de se esperar que ele esteja disposto e disponível a abrir um leque de possibilidades para que o aluno realize suas escolhas, relacionando os novos saberes com outros já construídos.

O que se tem observado atualmente é que, embora a educação à distância esteja sendo desenvolvida em diversas instituições, nem sempre encontramos o professor atuando de maneira interativa. Em geral, os cursos de EaD ainda estão presos a uma perspectiva educacional tradicional e que já não funciona mais nem presencialmente, tampouco à 


\section{AS TECNOLOGIAS E CULTURAS DIGITAIS NA EDUCAÇÃO A DISTÂNCIA}

\section{SIMONE LUCENA}

distância. Alguns cursos disponíveis na internet realizam discussões por meio de interfaces como fórum e salas de bate-papo. Nessas atividades, entretanto, o professor permanece com a mesma postura centralizadora da sala de aula presencial onde ele organiza e coordena as discussões. Ele provavelmente não percebe que na ambiência virtual, assim como na aula presencial, não precisa ser o centro do processo e responder a todas as perguntas. Um chat é um espaço onde todos interagem com todos e não apenas no sentido professor-aluno.

Diante desta situação, reforçamos que a interatividade depende muito mais de uma mudança de postura do professor e do aluno do que da inserção das tecnologias digitais. As TIC não irão resolver por si só os problemas da educação, uma vez que a interatividade não está nas tecnologias, ela está presente nas relações sociais que poderão ser mediadas pelas tecnologias.

Não queremos propor aqui receitas ou regras rígidas de como fazer uma educação a distância, até porque não há certezas e muita coisa ainda está por ser feita. Nossa prática pedagógica, bem como as pesquisas que realizamos no Grupo de Pesculta Educação e Culturas digitais (ECult/CNPq - http://grupoecult.blogspot.com.br) comprovam que não será possível fazer uma $\mathrm{EaD}$ com base na mesma perspectiva da aula convencional, uma vez que as TIC potencializam uma nova ambiência.

Acreditamos que para desenvolver uma educação com a utilização das culturas digitais, seja ela presencial, semi-presencial ou à distância, será importante um grande esforço dos profissionais da educação no sentido de concretizar a construção de ambientes de aprendizagem alternativos, onde os sujeitos envolvidos nesse processo tenham a possibilidade de criar, recriar, modificar, agir em tempo real, ser autores e co-autores de produções. Neste espaço de aprendizagem não haverá necessidade de "desintermediação" - retirada - do professor do processo comunicacional/educacional, pois ele será o agente mediador que desafiará constantemente o aluno no seu desenvolvimento cognitivo.

Desta forma, o processo de aprendizagem tornar-se-á uma produção coletiva, onde a construção do conhecimento poderá ser comparada a uma viagem no labirinto da informação (web) em que nenhuma parada (link) está definida e cada 'obstáculo' (nó) poderá ser um recomeço. Para navegar no labirinto, a alternativa não está em usar o fio de Ariadne, mas na dança dos gêranos onde todas as possibilidades poderão ser vivenciadas em tempos e espaços simultâneos.

Neste sentido, nós, educadores, temos muito a aprender com a chamada geração da "polergarzinha", que interage íntima e familiarmente com a tecnologia, criando, recriando, analisando e criticando tudo aquilo que lhe é pro(im)posto. Pensar em mudanças educacionais em curto prazo pode parecer uma utopia, contudo é necessário buscarmos um entre-lugar onde seja possível trabalhar com os limites e as possibilidades.

\section{Notas}

\footnotetext{
${ }^{\text {I }}$ Doutora em Educação. Professora do Departamento de Educação e do Programa de Pós-graduação em Educação da UFS. Líder do Grupo de Pesquisa ECult - Educação e Culturas digitais
} 
(http://grupoecult.blogspot.com.br). Artigo produzido a partir de pesquisas financiadas pela Capes e Fapitec-SE. Apresentado em palestra do Fórum das Licenciaturas da UFS em 2015.

${ }^{\text {II }}$ DELEUZE, Gilles. Diferença e repetição. Rio de Janeiro: Graal, 2009, p. 385.

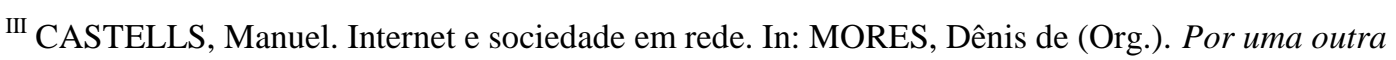
comunicação. Rio de Janeiro: Record, 2003, p. 255.

${ }^{\mathrm{IV}}$ DICIONÁRIO DE TECNOLOGIA. Tecnologia e lingüística e texto digital. São Paulo: Futura, 2003, p. 921.

${ }^{v}$ LÉVY, Pierre. O que é virtual? São Paulo: Editora 34, 1996, p. 12.

${ }^{\mathrm{VI}}$ CASTELLS, Manuel. A sociedade em rede. São Paulo: Paz e Terra, 1999.

${ }^{\text {VII }}$ BONILLA, Maria Helena Silveira. Escola aprendente: para além da sociedade da informação. Rio de Janeiro: Quartet, 2005, p. 131

${ }^{\mathrm{VIII}}$ SERRES, Michel. Hominescências: O começo de uma outra humanidade. Rio de Janeiro: Bertrand Brasil, 2003.

IX DELEUZE, Gilles. Diferença e repetição. Rio de Janeiro: Graal, 2009, p. 298

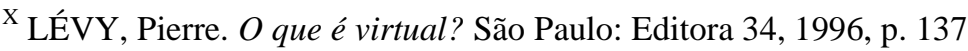

${ }^{\mathrm{XI}}$ BONILLA, Maria Helena Silveira. Escola aprendente: para além da sociedade da informação. Rio de Janeiro: Quartet, 2005, p. 132.

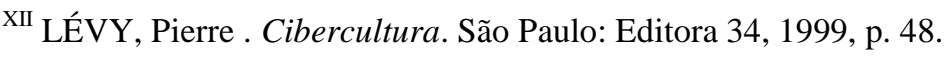

XIII Talvez pudéssemos comparar esses processos a outras teorias de desenvolvimento cognitivo, como por exemplo, aos estudos realizados por Vygotsky, para quem o conhecimento se constrói a partir da interação sujeito-objeto de conhecimento.

${ }^{\text {XIV }}$ LÉVY, Pierre. As tecnologias da inteligência. Rio de Janeiro: Editora 34, 1993.

xv LÉVY, Pierre. As tecnologias da inteligência. Rio de Janeiro: Editora 34, 1993, p. 29.

${ }^{\mathrm{xVI}}$ MACHADO, Arlindo. Máquina e imaginário: o desafio das poéticas tecnológicas. 3 ed. São Paulo: Editora da Universidade de São Paulo, 2001.

${ }^{\mathrm{XVII}}$ MACHADO, Arlindo. Máquina e imaginário: o desafio das poéticas tecnológicas. 3 ed. São Paulo: Editora da Universidade de São Paulo, 2001, p. 165.

XVIII SERRES, Michel. Hominescências: O começo de uma outra humanidade. Rio de Janeiro: Bertrand Brasil, 2003, p. 200.

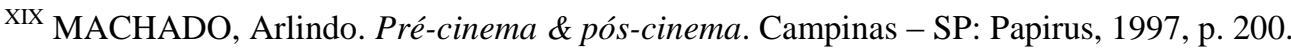

${ }^{\mathrm{xx}}$ LEMOS, André. Cultura das redes: ciberensaios para o século XXI. Salvador: EDUFBA, 2002.

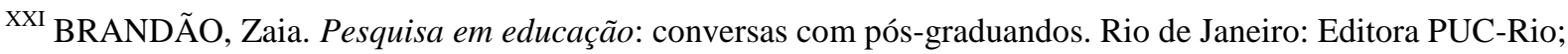
São Paulo: Loyola, 2002, p. 17.

${ }^{\text {XXII }}$ Ver exemplos em: www.prossiga.br e www.periodicos.capes.gov.br 


\section{AS TECNOLOGIAS E CULTURAS DIGITAIS NA EDUCAÇÃO A DISTÂNCIA}

\section{SIMONE LUCENA}

XXIII NIELSEN, JAKOB. Projetando websites. Reio de Janeiro: Campus, 2000, p. 15

${ }^{\text {XXIV }}$ LÉVY, Pierre . Cibercultura. São Paulo: Editora 34, 1999, p. 79.

${ }^{\text {xxv }}$ SILVA, Marco. Sala de aula interativa. Rio de Janeiro: Quartet, 2000.

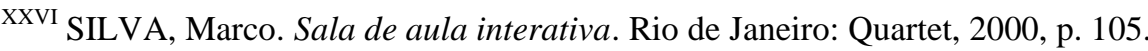

${ }^{\text {XxvII }}$ SILVA, Marco. O que é interatividade. Boletim Técnico do SENAC. Rio de Janeiro, v 24, n. 2, p. 27 a 35 , maio/ago, 1998, p. 29.

${ }^{\text {XXVIII }}$ COUCHOT, Edmund. A arte pode ainda ser, um relógio que adianta? O autor, a obra e o espectador na hora do tempo real. In: DOMINGUES, Diana (Org.). A arte no século XXI: A humanização das tecnologias. São Paulo: Editora da UNESP, 1997.

xxIX COUCHOT, Edmund. A arte pode ainda ser, um relógio que adianta? O autor, a obra e o espectador na hora do tempo real. In: DOMINGUES, Diana (Org.). A arte no século XXI: A humanização das tecnologias. São Paulo: Editora da UNESP, 1997, p. 137.

xxx LÉVY, Pierre . Cibercultura. São Paulo: Editora 34, 1999.

${ }^{\text {XXXI }}$ SILVA, Marco. Sala de aula interativa. Rio de Janeiro: Quartet, 2000, p. 20.

XxxII Alves e Nova (2003) apresentam uma coletânea de textos que tratam da EAD.

XxxIII Ver http://www.institutouniversal.com.br/ acessado em 25/08/2015

XXXIV PRETTO, Nelson De Luca. Uma escola sem/com futuro: educação e multimídia. Campinas-SP: Papirus, 1996.

${ }^{\text {xxxv }}$ FREIRE, Paulo. Educação e mudança. Rio de Janeiro: Paz e Terra, 1979.

${ }^{\text {XxxVI }}$ PRIMO, Alex. Quão interativo é o hipertexto? Da interface potencial à escrita coletiva. XI Encontro da Associação Nacional de Pós-graduação em Comunicação - Compós. UFRJ, junho 2002.

XxxvII Gilson Schwartz, coordenador do projeto "Cidade do conhecimento" (www.usp.br/iea/cidade), menciona a inscrição na torre da praça do relógio na USP onde está escrito que "no mundo da cultura, o centro está em toda parte", como referência para realizarmos conexões em todos as direções e sentidos.

xxxVIII TAPSCOTT, Don. Geração digital: a crescente e irreversível ascensão da Geração Net. São Paulo: Makron Books, 1999.

xxxIx SERRES, Michel. Polegarzinha. Rio de Janeiro: Bertrand Brasil, 2013.

\section{REFERÊNCIAS}


BONILLA, Maria Helena Silveira. Escola aprendente: para além da sociedade da informação. Rio de Janeiro: Quartet, 2005.

BRANDÃO, Zaia. Pesquisa em educação: conversas com pós-graduandos. Rio de Janeiro: Editora PUC-Rio; São Paulo: Loyola, 2002.

CASTELLS, Manuel. A sociedade em rede. São Paulo: Paz e Terra, 1999.

CASTELLS, Manuel . Internet e sociedade em rede. In: MORES, Dênis de (Org.). Por uma outra comunicação. Rio de Janeiro: Record, 2003.

COUCHOT, Edmund. A arte pode ainda ser, um relógio que adianta? O autor, a obra e o espectador na hora do tempo real. In: DOMINGUES, Diana (Org.). A arte no século XXI: A humanização das tecnologias. São Paulo: Editora da UNESP, 1997

DELEUZE, Gilles. Diferença e repetição. Rio de Janeiro: Graal, 2009.

DICIONÁRIO DE TECNOLOGIA. Tecnologia e lingüística e texto digital. São Paulo: Futura, 2003.

FREIRE, Paulo. Educação e mudança. Rio de Janeiro: Paz e Terra, 1979

LEMOS, André. Cultura das redes: ciberensaios para o século XXI. Salvador: EDUFBA, 2002

LÉVY, Pierre. As tecnologias da inteligência. Rio de Janeiro: Editora 34, 1993.

LÉVY, Pierre. O que é virtual? São Paulo: Editora 34, 1996.

LÉVY, Pierre . Cibercultura. São Paulo: Editora 34, 1999.

MACHADO, Arlindo . Pré-cinema \& pós-cinema. Campinas - SP: Papirus, 1997.

MACHADO, Arlindo. Máquina e imaginário: o desafio das poéticas tecnológicas. 3 ed. São Paulo: Editora da Universidade de São Paulo, 2001.

NIELSEN, JAKOB. Projetando websites. Reio de Janeiro: Campus, 2000.

PRETTO, Nelson De Luca. Uma escola sem/com futuro: educação e multimídia. Campinas-SP: Papirus, 1996.

PRIMO, Alex. Quão interativo é o hipertexto? Da interface potencial à escrita coletiva. XI Encontro da Associação Nacional de Pós-graduação em Comunicação Compós. UFRJ, junho 2002. 
SERRES, Michel. Hominescências: O começo de uma outra humanidade. Rio de Janeiro: Bertrand Brasil, 2003.

SERRES, Michel. Polegarzinha. Rio de Janeiro: Bertrand Brasil, 2013.

SILVA, Marco. O que é interatividade. Boletim Técnico do SENAC. Rio de Janeiro, v 24, n. 2 , p. 27 a 35, maio/ago, 1998.

SILVA, Marco. Sala de aula interativa. Rio de Janeiro: Quartet, 2000.

TAPSCOTT, Don. Geração digital: a crescente e irreversível ascensão da Geração Net. São Paulo: Makron Books, 1999. 